\title{
Protection of marine benthic habitats in the Pacific islands. A case study of Guam
}

\author{
Michael J. GAWEL* \\ Guam Environmental Protection Agency 120 Bengbing St., y-Papao Estates, Yigo, Guam, 96929 USA
}

Revised 11 October 1999; accepted 12 October 1999

\begin{abstract}
Guam consists of a single main island surrounded by shallow fringing coral reefs. The marine species and ecology of Guam's coral reefs have been studied extensively, especially through programs of the University of Guam's Marine Laboratory. In addition to overfishing and destructive fishing practices, the marine benthic communities of Guam have been damaged by major storm waves; loss of corals to crown of thorns starfish predation; damage by recreational swimmers, divers and watercraft operators; grounding of ships and pollutant discharges of sewage and of stormwater. But the most serious damage is due to accelerated siltation, sedimentation and turbidity due to erosion related to land use practices. Steps are being taken to protect Guam's coral reefs and coastal waters through legislation, regulations, permit systems and policies. Environmental impact assessments, Guam's Coral Reef Initiative and controls by the Guam Seashore Protection Commission help greatly in the protection of Guam's marine benthic environment, while new legislation and research to protect Guam's coral reefs is underway.@ 1999 Ifremer / CNRS / IRD / Éditions scientifiques et médicales Elsevier SAS
\end{abstract}

\section{reef / protection / benthic / environment / Guam}

Résumé - Protection de l'environnement benthique de l'île de Guam. Guam, dans l'archipel des Mariannes, est formée d'une île principale entourée d'une frange de récifs coralliens peu profonds. Les espèces marines et l'écologie y ont été beaucoup étudiées, en particulier par le laboratoire d'océanologie de l'université de Guam. Les communautés henthiques ont souffert de la surexploitation et des pratiques destructrices de la pêche, de la destruction par les vagues de tempête, de la disparition des coraux par une étoile de mer prédatrice et d'autres dommages causés par les baigneurs, les plongeurs et les engins motorisés. Mais les dégâts les plus importants résultent de l'envasement rapide, de la sédimentation et de la turbidité causée par l'érosion liée aux activités terrestres. Pour protéger les récifs coralliens et les eaux côtières, des mesures ont été prises dans la législation, la réglementation et les systèmes d'autorisations. L'évaluation de l'impact sur l'environnement par le Comité des récifs coralliens de Guam et les contrôles effectués par la Commission de protection du littoral ont contribué efficacement à protéger l'environnement de la faune benthique de Guam, tandis que s'élabore une nouvelle législation et que les recherches se poursuivent pour protéger les récifs coralliens de Guam. (C) 1999 Ifremer / CNRS / IRD / Éditions scientifiques et médicales Elsevier SAS

récif / protection / benthique / environnement / Guam

\section{INTRODUCTION}

Guam is the largest island in Micronesia, with a land area of $549 \mathrm{~km}^{2}$. Approximately half of the island is made up of volcanic rocks and soils with relatively steep slopes and numerous river valleys. The other half is formed from ancient raised coral reefs, which in some places rise to over $200 \mathrm{~m}$ above sea level.

Well-developed coral reefs surround most of the island, usually in the form of fringing reefs with shallow reef flats that in some places extend more than $500 \mathrm{~m}$ offshore. Lagoons enclosed by barrier reefs occur at Cocos

* Correspondence and reprints: mgawel @ìns.gov.gu 
Lagoon in the south and at Apra Harbor on the central west coast. Although Cocos Lagoon is less than $10 \mathrm{~m}$ deep, parts of Apra Harbor are over $45 \mathrm{~m}$ in depth, providing some deeper lagoonal habitats with both live coral and unconsolidated sediment bottoms. Guam also has several patch reefs outside its fringing reefs and others inside its lagoons.

Much of Guam's fringing reef area is bounded by submerged terraces at ancient sea stands currently at depths of 30 to $50 \mathrm{~m}$. Sea slopes from Guam drop steeply to over $1000 \mathrm{~m}$ depth off the west coast and on the east to the Marianas Trench, which reaches depths of over $10000 \mathrm{~m}$ just $80 \mathrm{~km}$ offshore.

Within Guam's 200 mile Exclusive Economic Zone (EEZ) there are at least five deepwater coral reef banks with minimum depths between 5 and $60 \mathrm{~m}$. A recent report by Green [1] estimates that there are $179 \mathrm{~km}^{2}$ of reef areas around Guam which are at less than $100 \mathrm{~m}$ in depth. Less than half, or $69 \mathrm{~km}^{2}$, of these reefs are within 3 miles of the main island, while $110 \mathrm{~km}^{2}$ are included in distant banks within the EEZ as indicated in figure 1 . These banks are frequently fished by Guam's recreational and small boat commercial fishermen. Other significant banks with unknown resources average approximately $1000 \mathrm{~m}$ in depth and lie to the west of Guam.

Guam was settled by Chamorros over 3000 years ago. The population was estimated to be over 100000 in 1521, when villagers discovered Magellan and his European crew on their shores, following their Pacific crossing. After colonization by Spain for almost three centuries and capture by the United States in 1898 , Guam's native population declined and mixed with immi-

\section{O BANK "A"}

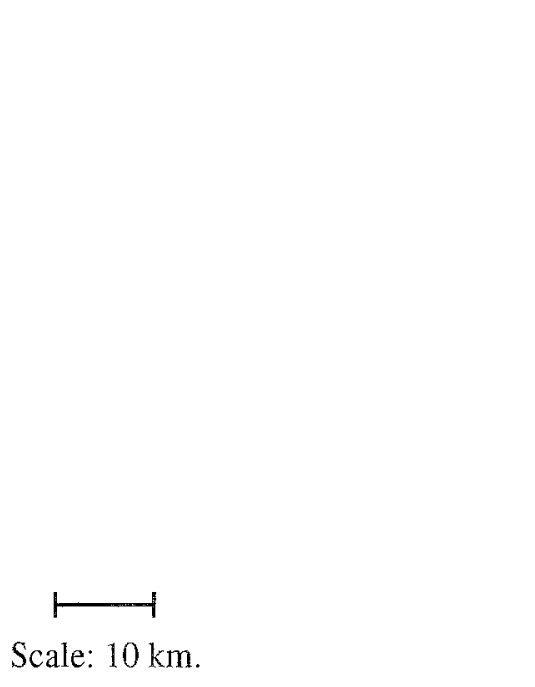

0

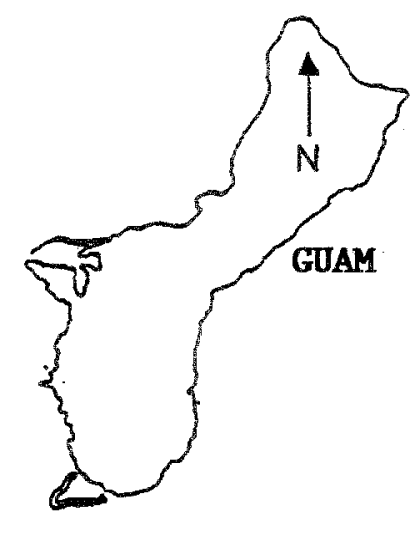

3 GALVEZ BANK

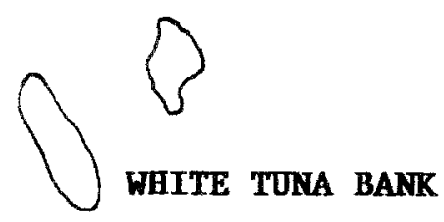

Figure 1. The Island of Guam and its outlying coral reefs and banks. 
grants from Europe, Asia and America. In 1941 Japan seized Guam from the United States and ruled it as a war prize until 1944, when returning US forces liberated the island. Most traditional marine resource use and management practices, which evolved in Guam over thousands of years, had been lost during the periods of colonial occupation.

Nevertheless, seafood has remained important in local diets and preferences and recreational fishing is still widely practiced. New fishing technologies and equipment have been introduced to Guam since World War II, as the population demanding seafood has grown. Before the war, in 1940, Guam had approximately 23000 residents. This number grew to 59000 in 1950 , partly due to temporary populations at military bases and foreign construction workers. Currently Guam is losing large percentages of military residents and has a total of just over 150000 residents [2]. Market demands have resulted in over US $\$ 22000000$ worth of seafood being imported to Guam annually.

Guam's present economy is based upon income generated by the 1400000 tourists visiting annually. A rapid growth in tourism-related construction during the last decade has resulted in many negative impacts on marine habitats. But tourism has also brought benefits because Guam's clean, healthy coastal waters and coral reefs are what attract tourists. Coral reef-dependent passive activities including diving, tourist submarines, dolphin watching boats and an underwater observatory account for over US $\$ 10500000$ of Guam's monthly economy [3]. Efforts to protect Guam's marine habitats and to enhance coral reef quality contribute to the sustainability of the tourism industry.

\section{BENTHIC MARINE HABITAT ASSESSMENT}

Information on Guam's benthic marine habitats and their living resources is quite extensive. Since the late $1960 \mathrm{~s}$ the University of Guam Marine Laboratory has been carrying out research, studies and assessments on marine organisms and ecosystems, especially concentrating on Guam's coral reefs. Over 375 referred scientific papers published in internationally recognized journals as well as conference proceedings and books have been produced by the Marine Laboratory's stafl and students, while 95 Masters of Science theses have been produced, most of them dcaling with marine benthic organisms and ecosystems [4]. Some examples of theses include 'Effects of fishing pressure on the reef flat fisheries of Guam' and 'Long-term recovery processes of a coral reef community after a catastrophic disturbance'. Seven permanent researchers holding $\mathrm{PhDs}$ are employed by the Marine Laboratory, as well as support staff and temporary student and post-doctorate researchers. Guam's requirement for environmental impact assessments (EIAs) before permission is given for developments have led to scores of site-specific assessments of benthic communities. EIAs normally provide descriptions of the geological and physical oceanographic characteristics of a site and list abundances of macroscopic benthic species.

\section{RESULTS}

Studies, monitoring and investigations by the University, the Guam Environmental Protection Agency and the Guam Agriculture Department's Division of Aquatic and Wildlife Resources have identified a number of categories of causes of negative impacts on Guam's benthic communities. More detailed presentations on coral reef responses to impacts arc contained in Birkeland $[5,6]$.

\subsection{Natural damage}

Natural causes of significant localized losses of corals have included storm waves and crown of thorns starfish predation. Guam is subject to tropical storms and typhoons, with direct passage over the island of typhoons or supertyphoons at least once a decade. These produce storm waves that break coral and move large submerged boulders even at depths of greater than $20 \mathrm{~m}$. In 1969 and 1970 extensive killing of hard corals by Acanthaster planci occurred on Guam, but numbers of this coral predator have since decreased to normal population levels.

\subsection{Anthropogenic damage}

Humlan-caused categories of problems include destructive fishing, overfishing, damage by swimmers and divers, damage by small watercraft, military exercises, grounding of ships, sewage discharge, stormwater discharges and land erosion impacts of siltation, sedimentation and turbidity.

Fishing with explosives and with bleach and other poisons occurred frequently during the decades after World War II. However, stricter laws and a record of severe courtimposed penalties have practically eliminated destructive 
fishing practises in Guam over the last 15 years. Boats and trucks have been confiscated and forfeited as part of the effort to stop fishing with explosives and poisons.

Overfishing has remained a scrious problem which should be better controlled following the implementation of new Guam fishing regulations which were legally adopted in May of 1997 and come into effect in 1999.

The rapidly increasing recreational swimming, snorkelling and diving on Guam has resulted in significant accidental damage to living corals. Guam has certitied almost 4000 new scuba divers annually, more than any location except the United States. Guam's recreational diving industry generates more than US $\$ 1500000$ per month in economic activity [3].

Active marine activities include riding jet skis, which have an impact on shallow benthic coral and seagrass growth, even causing slight pressure fractures in branched corals which, as a consequence, are unable to withstand even mild storm waves. They also disturb fish and other marine life and add oil and gasoline to coastal waters. Small diving and fishing boats also damage corals while anchoring. Military exercises carried out in Guam by the US Department of Defense make use of landing craft which damage shallow coral colonies and set off explosives underwater which can harm corals, fish, turtles and marine mammals. Large transoceanic fishing, cargo, cable and other ships have grounded on Guam coral reefs, crushing benthic communities and sometimes spilling fuel.

Guam's great increases in developments and population have generated amounts of sewage and stormwater which have not been adequately disposed of and therefore have polluted marine habitats. Although sewage treatment plants exist which can treat over 20000000 gallons per day of wastewater, they are often overloaded or malfunction and their ocean outfalls should all be deeper to avoid impacts on reef communities [7].

Finally, the accelerated rate of soil erosion on Guam due to land clearing, off-road vehicle use, grassland fires and construction excavation has been the worst source of coral reef destruction on Guam in recent years. The steep-sloped volcanic soils of southern Guam have been increasingly causing sedimentation and siltation which smothers benthic marine life, while finer particles of eroded soil create chronic turbidity which blocks sunlight from the photosynthetic algac in recf-building corals, giant clams and other organisms $[8,9]$.

\section{MANAGEMENT MECHANISMS}

Anthropogenic causes of marine benthic community damage may be controlled by managing human activities. New marine resource management techniques have tried to meet pressures on the resources and are still under development. Some of the existing approaches used in Guam to control human impacts are legislation, permits, policies, plans and education.

\subsection{Legislation}

International treaties, US Federal laws and local laws all apply on Guam. Those relevant to protecting marine benthic environments include the following.

\subsubsection{International Law}

- Convention on International Trade in Endangered Species (CITES), which prohibits trade in many coral reef species.

\subsubsection{United States Federal Law}

- Rivers and Harbors Act of 1898, which regulates filling and excavating of submerged areas.

- National Environmental Policy Act of 1969 and its amendments of 1978, which creates an Environmental Protection Agency to comprehensively solve environmental problems.

- Coastal Zone Management Act of 1972, which funds planning, education and other activities to protect marine benthic areas and requires local government approvals of activities which have an impact on the marine environment.

- Endangered Species Act of 1973, which protects listed endangered species such as sea turtles and their critical habitats.

- Clean Water Act of 1977, which controls the quality of marine waters.

\subsubsection{Guam Law}

- Fisheries Regulations which limit methods and seasons for fishing as well as species sizes and which create marine preserves in which fishing is restricted. (Guam Code Title 5, Chapter 63 and Public Law 24-21). 
- Guam Seashore Protection Act, which requires public hearings and commission approval for all developments sited in coastal waters up to sixty feet deep and on coastal land up to $100 \mathrm{~m}$ from the high tide mark. (Guam Code Title 21, Chapter 63).

- Guam Environmental Policy Act, which created the Guam Environmental Protection Agency and its Board of Directors in 1973. (Guam Code Title 10, Division 2, Part 2).

- Guam Land Usc Plan and Zoning Code, which revises planning and zoning to recognize a specially designated marine zone and creates a development permit system which comprehensively applies EIAs and performance standard regulations to every new development. (Public Law 24-171).

- Guam Coral Reef Initiative, which recognizes the values of coral reefs and sets government priorities for their conservation. (Executive Order 97-10).

\subsection{Permits}

Some Guam permits assisting in protection of marine habitats are the Seashore Protection Permits, Water Quality Certification, Dredging and Filling Permits, Wetland Use Permits, Clearing and Grading Permits, National Pollutant Discharge Ellimination System Permits and Coastal Resources Management Federal Consistency Permits.

\subsection{Policies}

Policies that affect marine environments include keeping discharges to water bodies within the ambient water quality levels, denying construction of coastal groins, requiring EIAs, requiring mitigation for impacts on resources, requiring best management practices for aquaculture developments, formally analysing alternatives to proposed developments, etc.

\subsection{Plans}

Plans with an impact on the marine environment in Guam include the Seashore Reserve Plan, the Land Use Plan, wastewater management plans, stommater drainage plans, watershed management plans, the Recreational Water Use Management Plan, spill clean-up contingency plans and commercial port development plans.

\subsection{Education}

The basis of successful marine benthic habitat protection is education of the public and government leaders. Guam's Coastal Resources Managcment Program takes the lead in education on coastal matters by producing monthly television shows and newsletters and by developing educational materials including videos, posters, booklets, maps, research reports and news articles. The University of Guam, the Guam Department of Education and the Division of Aquatic and Wildlife Resources also produce educational materials on coral reef resources. A non-governmental organization called 'Kids for Coral' has undertaken numerous educational activities to protect coral reef ecosystems, including fund raising to finance production of numerous copies of the new Guam video 'Coral Reefs: Their Health, Our Wealth'. Additionally, public hearings on proposed developments offer a means of informing the public of possible consequences of project approvals.

\section{CONCLUSIONS}

Numerous management activities are helping to protect Guam's marine benthic habitats, but mechanisms developed specifically to protect valuable marine benthic communities are lacking. New laws, regulations, plans and policies directly addressing coral reef ecosystem protection are needed. The Guam governors Executive Order 97-10, of May, 1997, formally establishes Guam's Coral Reef Initiative, designates a policy advisory commission and calls for creation of appropriate laws and policies to protect Guam's coral reefs.

\section{Acknowledgements}

The author wishes to thank the following, without whose valuable assistance this paper could not have been produced: the author's employer, Guam Environmental Protection Agency, managed by Ješis T. Salas; the Guam Coral Reef Initiative Coordinating Committee, including Dr Robert Richmond, Michael Ham and Gerald Davis (who provided figure 1); SOPAC and IFREMER, supporters of the Noumea Conference on Marine Benthic Habitats and Their Living Resources; Mrs Agnes Garrido, who promptly and cheerfully translated the resume into French; the author's wile, Isabel and children AnnMarie and James who understand his dedication to coral reef ecology; and other co-workers and associates who provided various information and support. 


\section{REFERENCES}

[1] Green A., An assessment of the status of the coral reef resources, and their patterns of use in the US Pacific Islands, Western Pacific Regional Fisheries Management Council, Honolulu, 1997, 275 p.

[2] Bureau of Planning, Government of Guam, Guam 1997 Social and Economic Indicators, 1998, $8 \mathrm{p}$.

[3] Bureau of Planning, Government of Guam, Unpublished notes, Coral Reef Initiative, 1998, $10 \mathrm{p}$.

[4] University of Guam Marine Laboratory, Contributions, University of Guam Marine Laboratory, 1997, 60 p.

[5] Birkeland C., Status of coral reefs in the Marianas, in: Grigg R.W., Birkeland C. (Eds.), The Status and Health of Coral
Reefs in the Pacific - 1997 - the International Year of the Reef, Univ. Hawaii Sea Grant, Honolulu, 1997.

[6] Birkeland C. (Ed.), Life and Death of Coral Reefs, Chapman $\&$ Hall, Melbourne, 1997, $536 \mathrm{p}$.

[7] Guam Environmental Protection Agency, Guam Water Quality Report to Congress, $1998,98 \mathrm{p}$.

[8] Richmond R., Coral reefs: present problems and future concerns resulting from anthropogenic disturbance, Amer. Zool. 33 (1993) 524-536.

[9] Richmond R., Coral reef resources: pollution's impacts, Forum 9 (1) (1994) 54-57. 